\title{
Problemet med det multimediale samfunnet ${ }^{1}$
}

Det er ikke antall kanaler og plattformer som sikrer demokratiet vårt. Det fungerer bare så lenge vi respekterer hverandre som mennesker med rett til divergerende meninger.

Ingen ønsker seg tilbake til det statlige mediemonopolet. Da det ble brutt på 80tallet, var det mange som mente at flere kanaler ville styrke demokratiet, både nasjonalt og på det lokale plan. Senere har vi jo også fått et stort antall digitale plattformer, der alle kan delta og si hva de mener. Dette er utvilsomt verdifullt, men etter de dramatiske hendelsene nå i januar i Washington D.C., er jeg slett ikke sikker på at demokratiet er blitt styrket.

Demonstrantene kom fra vidt forskjellige miljøer. Her var det nynazister og våpenentusiaster, rasister, nasjonalister og evangelikale kristne, de fleste av alle disse tilsynelatende Trump-tilhengere. Noen av de som snakket med journalister, sa at de var der for å ta tilbake landet og friheten som var blitt stjålet fra dem. Dette var ikke noe de hadde kommet på selv. De reflekterte tanker og ideer som har florert i ulike TV kanaler og ikke minst på sosiale medier.

Kan forklaringen på at en faktisk tror på disse konspirasjonsteoriene være at mangfoldet av medier og digitale plattformer gjør det mulig å leve seg inn i en egen boble? Her fremstår løgnene etter hvert som sannheter, fordi de blir gjentatt ofte fra kilder man stoler på. Samtidig er divergerende synspunkter og argumenter fraværende. I dette ekkokammeret blir lyden av egne argumenter reflektert og forsterket.

Tilhengerne av konspirasjonsteorier ser nødvendigvis på meningsmotstanderne med den aller dypeste skepsis, og vise versa. Det politiske landskapet vil alltid være preget av forskjellige syn, og større og mindre splittelser. Men det vi nå har sett i USA, er fundamentalt forskjellig fra vanlig politisk uenighet. Jeg tror at det multimediale samfunnet har bidratt til å muliggjøre dette.

Som mangeårig journalist og journalistlærer, er jeg av den oppfatning at ytrings- og pressefrihet er en bærebjelke for demokratiet. Men det som nå skjer, er et tydelig eksempel på at ytringsfriheten i seg selv ikke skaper et demokrati. Folk som i ytringsfrihetens navn fremsetter de mest urimelige påstander, skaper et farlig samfunn. Ende verre blir det når motparten møter dem med hån og latterliggjøring.

Et demokrati er avhengig av at de meninger som fremsettes blir lyttet til med respekt av meningsmotstanderne. Demokratiet krever ikke at alle skal være enige, men at meningene brytes $\mathrm{i}$ åpen debatt, der det beste argumentet vinner, og at taperne i debatten respekter at de ikke nådde fram. Taperne må perfeksjonere eller forandre sine standpunkter for å vinne fram i den videre debatten.

Vi har ikke amerikanske tilstander her i Norden, men jeg synes at vi ser en tiltagende uforsonlig debatt for eksempel når det gjelder livssyn. Vi kristne har en tendens til å føle oss forfulgt av våre liberale meningsmotstandere, mens vi beskyldes for å forårsake dårlige levekår. Vi blir truet til taushet med at våre kristne standpunkter oppfattes som krenkende. Dermed blir debatten mer preget av følelser enn av rasjonelle standpunkter.

Løsningen på dette er ikke at alle til slutt blir enige, eller at motparten blir tvunget til taushet, men at debatten blir mer preget av gjensidig respekt. Dette kan oppnås ved at partene ikke bare lytter til synspunkter de allerede er enige i, men også mottar impulser fra medier og plattformer som ikke preges av deres syn.

Dersom meningsmotstandere ikke bare skaffer seg innsikt i motpartens argumenter, men også oppdager hvorfor andre mener det de mener, er det ikke sikkert en blir 


\section{Theofilos}

A Nordic open access journal in Theology, Philosophy and Culture

Published by NLA University College - in partnership with Johannelund School of Theology

Available at www.theofilos.no

enige, men nytt lys over diskusjonen kan resultere i økende respekt for andres syn. Det igjen vil senke temperaturen i en ofte opphetet debatt. Lys er ofte bedre enn hete når det gjelder meningsutveksling.
${ }^{1}$ En lengre versjon av denne artikkelen er tidligere publisert i Fodrelandsvennen 13/1-21 og i Dagen 4/2-21.

\author{
Kåre Melhus \\ Førstelektor emeritus \\ NLA Høgskolen, Kristiansand \\ karemelhus@gmail.com
}

\section{I dette nummer ...}

Velkommen til den første ordinære utgaven av Theofilos som open access tidsskrift. Vi håper at mange av våre lesere har hatt utbytte av det innholdsrike temanummeret om «Science, Natural Theology, and Christian Apologetics». ${ }^{1}$ Det er nå en glede å kunne presentere et omfattende dobbeltnummer med bredde, dybde og aktualitet.

Demokratiet fungerer best når vi evner å respektere andre, samtidig som vi søker å fremme våre egne overbevisninger med åpne premisser og saklige argumenter. Denne betimelige påminnelsen fra Kåre Melhus i vår innledende lederartikkel, gjelder også et tidsskrift som Theofilos. Derfor løfter vi også frem betydningen av gode forskningsetiske og publiseringsetiske holdninger på theofilos.no. ${ }^{2}$

De tre første artiklene i academia omhandler sentrale kristne personligheter $\mathrm{i}$ Norden på 1800-tallet. I anledning 150årsjubileet av Landstads Kirkesalmebok i 2020, presenterer Egil Sjaastad en analyse av eskatologien i salmene til den norske dikteren. På bakgrunn av en undersøkelse av utvalgte prekenutkast, gir Torbjörn Larspers et bilde av den svenske vekkelseslederen Carl Olof Rosenius som forkynner. Tomas Bokedal drøfter danske Søren Kierkegaards kommunikasjonsstrategi i sitt forfatterskap, med vekt på direkte-indirekte meddelelse og den kristne troens hvordan.

I neste bidrag beveger vi oss nærmere vår egen tid. Simeon Ottosen foretar her en sammenligning av argumentasjonen for Bibelens ufeilbarlighet hos den norske teologen Carl Fredrik Wisløff og «Chicago Statement on Biblical Inerrancy».

Academia avrundes med tre artikler som omhandler dagsaktuelle temaer. Joel Halldorf analyserer Sverigedemokraterna som et høyrepopulistisk parti, ut fra flytende modernitet, eksistensiell angst og relasjonen til faste kirkegjengere som perspektiv. Profetiene om Donald Trump, USA og Guds rike innenfor New Apostolic Reformation-bevegelsen står i fokus i Arne Helge Teigens kritiske undersøkelse. I den siste artikkelen er vi over i kirkerommets verden. Hans-Olav Hodøl drøfter her bruken av digital presentasjonsteknikk i gudstjenester, og inkluderer også noen praktiske råd.

Per-Axel Sverker innleder forum-delen av dette nummeret med en artikkel om John Stott som «evangelikal kirkefader». I april 2021, er det 100 år siden den profilerte britiske forfatteren, forkynneren og misjonslederen ble født. I neste bidrag foretar Fernando Vasques en sammenligning mellom Francis Jonbäcks Meningsfullt liv og Martin Hägglunds Vårt enda liv: sekulär tro och andlig fribet, med utgangspunkt i spørsmålet hvorvidt ateismen kan være eksistensielt relevant.

Olof Edsinger presenterer så en bibelteologisk drøfting av uttrykket «mannen som kvinnens hode», med en intensjon 